\title{
The Contribution Of Ecofeminism Philosophy In Environmental Management Research
}

\author{
Hamidi Ismail \\ Development Management Programme, School of Government, Universiti Utara Malaysia \\ 06010 UUM Sintok, Kedah, Malaysia, Email: hamidi@uum.edu.my

\section{Tuan Pah Rokiah Syed Hussain}

Development Management Programme, School of Government, Universiti Utara Malaysia 06010 UUM Sintok, Kedah, Malaysia, Email: sh.rokiah@uum.edu.my

\section{Muhammad Subhan}

School of International Studies, Universiti Utara Malaysia, 06010 UUM Sintok, Kedah, Malaysia

Email: msubhan@uum.edu.my

\section{Doi:10.5901/mjss.2016.v7n1s1p335}

\begin{abstract}
The diversity of philosophy in exploring knowledge has different directions and different viewpoints. Nowadays, the philosophy behind exploration of knowledge lies mostly in the nature of the interaction between humans and the natural environment based on the ecocentrism philosophy. However, in the struggle for the environment, women also play an important role alongside men and this is highlighted in a form of philosophy known as ecofeminism. Nonetheless, the issue is actually on the structure of knowledge exploration of the woman movement in environmental preservation throughout the decades of their struggle. This paper aims to basically look at the ontology, epistemology, methodology and axiology behind the philosophy of women's struggle in environmental preservation. This paper found that the women's struggle has a distinctive contribution that is able to advance their involvement in preserving the environment. This struggle is clear in the context of the structure of knowledge itself based on its ontology, epistemology, methodology and axiology. Among the contributions etched in history today are through the importance of gender in the questionnaire, so that the findings could differentiate between men and women.
\end{abstract}

Keywords: Philosophy studies, environmental studies, ecofeminism, women, management

\section{Introduction}

Early philosophy such as ethnocentrism states that man is the focus of development. The ideology of philosophy has some impact on the balance of the ecosystem and human life. From another point of view, the philosophy of ecocentrism became well-known for its ability to harmoniously create a human and physical environment. On the other hand, there is a fight to protect the environment based on the struggle of women. The struggle of this group has its own history and ideology, referred to as the philosophy of ecofeminism. This philosophy is different from other ideologies in the context of knowledge based on its aspects of ontology, epistemology, methodology and axiology. Therefore, this article aims to look at the fundamental knowledge of ecofeminism through its ontology, epistemology, methodology and axiology.

This philosophy has developed because of awareness of the importance of women's role in the preservation of the environment which puts them in a broader struggle on a par with men. The ideology of men's struggle is said to still have weaknesses which needs the support of women. In fact, women perceive the environment as more closely related with their lives. For example, in terms of individuals, household and lifestyle which frequently use natural resources wisely, such as water and plants. Thus, women are considered more appreciative of nature than men who have create environmental pollution for decades. Therefore, Gaard (1998; 2001) and Vardey (1995) argued that, women should be given particular attention and place in the fight to protect the environment.

\section{The Struggle of Eco-feminists for the Environment}

Classical philosopher Aristocles (or known as Plato) (427-347 BC) stated that "... a man is not entitled to anything." From 
his lecture to his students, it reflects that nature belongs to all creatures (Mohammad Hatta, 1982). This early philosophy proves that all things that exist in the universe need one another to care for them. The care of concrete existence according to Plotinus (205 AD) should be based on axia or morality and ethics to all beings. Findlay (1970) and Rescher (2005) said that the context of examining certain knowledge or subject is called axiology. Morality and ethics is the duty of every human, regardless of gender. Because women are part of nature, they are also important in protecting the environment as much as men.

\subsection{The Ontology of Ecofeminism's Struggle for Environmental Management}

According to Farber (2006), Jacquette (2002), and Ritchie and Lewis (2003), ontology is a branch of metaphysics on the existence of being and spiritual in nature, and it has been around since the dawn of Greek civilization. Griswold (2001) stated that ontology is composed of onto-, from the Greek which means "what happens and occurs in a society, science, research or theory", and -logos which means "the science or study of something". In other words, ontology is the knowledge of what happens in this world. Among early or classical prominent figures in ontology are Thales (625-545 BC), Plato (427-347 BC) and Aristotle (384-322 BC). They are best known for their real-world philosophy, such as water is the source of life and nature is closely related to water. Indeed, what is important is that ontology discusses a subject or field of knowledge being researched by someone. Occasionally, ontology refers to a domain of certain knowledge that someone intends to study.

The philosophy of ecofeminism is made up of two different morphemes; the first is "eco" which refers to the ecology of life, such as the physical environment, either human or non-human like plants and animals. The second morpheme is "feminism", which is derived from the philosophy of fighting for the interests of women in the social system, economy, politics, culture, language or way of life in general. According to Gracia (1989), ontology in ecofeminism's struggle, particularly the group Radical Ecofeminism, is based on the natural environment which includes humans and other living forms, especially animals. The term ecofeminism may first be used by the French writer Françoise d' Eaubonne in her book, Le Féminisme ou la Mort in 1974 (Freedman, 2003). Women's rights group argues that there is a historical relationship between women and nature that should be shared. According to Shiva (1988), women have a unique relationship with the natural environment through their daily interactions, but any kind of relationship with nature has been ignored, such as points of view, activities and politics of environmental preservation. This is despite the fact that women are important contributors of livelihood and in the creation of wealth based on the natural environment. The feminists' plight is not only for the environment, but also beyond the borders of society, culture, language, religion, politics, economy and so on. In fact, feminism is a movement and ideology that aims to determine, define and defend equal rights in politics, economy, environment and society for all women or men (MacGregor, 2006; Biehl, 1991).

The philosophy of ecofeminism has two distinct branches, which are liberalism and conservatism. Liberal feminism seeks to emphasize the equality of men and women through political and legal reform without changing the structure of society. Conservative feminism refers to where members of a community reside and they are entitled to absolute freedom from coercive interference. It is also known as libertarian feminism (Price \& Shildrick, 1999; Ruether, 2003). In the 20th century, the post-structural and post-modern feminism argued that the concept of gender equality in liberal feminism through social discourse, economy, politics and the environment needs to be addressed properly (Narayan, 1997). This agrees with Abbot et al. (1996) and Ogunyemi (1985) who stated that feminism should be based on both men and women playing equal roles together to build the country or community.

\subsection{Epistemology of Ecofeminism's Struggle for Environmental Management}

The study of epistemology according to Farber (2006) emphasizes on the pursuit of knowledge or how we acquire knowledge. The word epistemology is derived from episteme (knowledge) and logos (study or theory). In other words, epistemology refers to the process of acquiring knowledge on something and how it is related to something else, or how humans can learn on a subject more clearly based on existing knowledge. Thus, epistemology is the philosophy of rational or empirical knowledge. However, Ritchie and Lewis (2003) explained that the process of knowledge acquisition should also involve interpretivism as practiced by the proponents of phenomenology.

According to Farley (2003) and Harding (2003), moral and political outlooks of feminist groups have inspired members of social sciences and biology to come up with critical questions about the process of traditional research, such as to include aspects of gender, relationship within or between the social world and the natural environment. In fact, some supporters of feminism, such as Ruth Hubbard and Evelyn Fox Keller criticized traditional scientific discourse because history tends to emphasize the male perspective (Blain et al. 1990; Freedman, 2003). Therefore, part of the agenda of the 
feminist research process seeks to identify where power inequalities exist, and thus, strengthen it in the scientific or academic paradigm (Messer-Davidow, 2002). According to Anderson (2011), epistemology of feminism is quite different from social studies as it stresses the importance of gender in the process of acquisition of knowledge on the natural environment. For him, the epistemology in the process of good environmental studies emphasizes on women in any form of social studies or environmental preservation. For Lynn (1990), empirical studies based on feminist groups have found that there are fundamental differences between the experiences of men and women. Therefore, feminist groups work towards acquiring knowledge through the study of women's experiences in order to strengthen scientific research.

\subsection{Methodology of Ecofeminism's Struggle for Environmental Management}

In recent decades, researchers prefer to use the word method of study or research approach. However, from the perspective of philosophy of knowledge, it is a scientific process of exploration of knowledge based on philosophy. The use of the term methodology is more appropriate because it describes the process of acquiring information for the purpose of study. Indeed, method is just part of the process of acquiring information in the framework of methodology. According to Creswell (1998; 2003), the philosophy of methodology should emphasize the process of acquiring information, such as the type of information, the sampling design and process analysis. Based on the opinion of Franklin (2012), for the purpose of research, a clear methodology should be used to reflect the ontological and epistemological study of that knowledge. In fact, Ritchie and Lewis (2003) argued that the study of environmental management can be divided into two, namely quantitative and qualitative. Qualitative findings cannot be made to be too objective and explanation related to the research findings should be conducted by the researchers themselves. On the other hand, Guba and Lincoln (1989) think that quantitative studies should only translate meaning of data for the purpose of describing the state of society along the lines of empiricist or positivist.

The research methodology of women's groups in the context of ecofeminism philosophy often states that they should also contribute ideas on how to create a sound natural environment. In this case, gender is an important element to be included as a basis of the study because both male and female perspective can produce different results and findings (Lindlof \& Taylor, 2002). According to Firestone (1970), history has always put research methodology on the study of women to be oriented towards women as a sex symbol, mother, wife, mistress and victim of abuse or persecution for the sake of men. All the while, the role of women is more than just a symbol or satisfaction for men. Nowadays, women's roles include educating children at home, joining the workforce, saving the environment and staying active in the family institution, similar to that of the third wave feminism in the twentieth century in the United States of America, the United Kingdom and France. This third wave feminism originated in the first wave feminism, which began in the early nineteenth century when women fought for their right to vote. Then, around the 1960s, the second wave feminism took place which demanded the freedom from the shackles of men. As we can see, research methodology based on the ecofeminism approach in environmental studies is part of the third wave. As pointed out by Lynn (1990), the methodology is also clearly characterized by the need to put the element of gender in a quantitative or qualitative study.

\subsection{Axiology of Ecofeminism's Struggle for Environmental Management}

According to Findlay (1970) and Rescher (2005), axiology emphasizes values and ethics in the study of mankind, as in the knowledge of evaluation of human behaviour and the importance of such knowledge for mankind in general. In fact, the word axiology itself is composed of axia which means value or worth, and logos which means the study or theory of something. Ritchie and Lewis (2003) stated that value of something is very objective, if it is measured based on something real like the mind frame of a positivist or an objectivist who emphasizes quantitative methods. In addition, value can also be subjective if it involves thoughts, intellect and human points of view as practiced by phenomenologist or interpretivist through samples of qualitative research. Whatever method of study, either quantitative or qualitative, values and ethics should be applied so that the research demonstrates appreciation for knowledge and humanity.

The importance of values and ethics is clear, as advocated by Françoise d'Eaubonne (Freedman, 2003), Sallie McFague (McFague, 1987) and Vandana Shiva (Shiva, 1988) who stated that women have their place in preserving the environment. They pointed out that in saving the planet, the western society often asserts that men have better values than women. Yet, good values and ethics do not reside in mankind, but only exist in the nature of a supreme being (McFague, 1987). Both men and women have weaknesses and strengths, and should complement each other in order to protect the ecosystem. According to Fricker (2009), Griffin (1978), Hampson (1990) and Strong (1995), a measure of these values are often forgotten, but they are important to be applied in research, such as sincerity of the soul in caring for the environment which is often associated with women. Therefore, in order to create better and thorough research, the 
aspect of value must be regarded as the basis of research, taking into account values and ethics inherent in women rather than men.

\section{Ecofeminism and Its Contribution to the Philosophy of Knowledge}

The philosophy of ecofeminism has its advantages because it emphasizes on a gender group in a study of social ecology or human habitat. It stresses on not only gender roles, but also aspects of emotions, thoughts, points of view, actions and way of life of women, which are said to be different from men's. This is not unusual, because in social studies and human relationship with the environment, it is considered important and is practiced in almost all social studies. Despite criticism against ecofeminism which alleges that ecofeminism's demand on gender equality in various aspects of life is excessive or sometimes has no clear direction in their struggle for the environment, their presence indicates that environmental care should be shared between the sexes. Currently, the importance of women's involvement in caring for the environment cannot be denied because they function significantly in the workforce, home, education, politics, business and religion.

Ontology of knowledge backed by ecofeminism is clear in the preservation of the environment in the context of knowledge about the natural world. In the context of epistemology, women's fight to protect the environment is said to have a favourable effect practically and psychologically compared with men. Similarly, methodologically speaking, women have a slightly different approach for incorporating elements of feminine emotions or gender in their struggle. On the other hand, in terms of axiology, this group stresses that women have the same role as men and in some cases, women are considered better than men because they are very appreciative of nature. As we can see above, it is a fact that women are important in preserving the quality of the natural environment compared with men. Therefore, this group will always champion the cause of women in promoting a sustainable environmental management.

Although the philosophy of knowledge on discovering and managing the environment is diverse, such as ethnocentrism, ecocentrism, naturalism, biocentrism, animalism, ecofeminism and deep ecology, the philosophical approach that is often used is ecocentrism. This is because, as Jahi (1996) puts it, humans live and function in a habitat that is often using materials, technology and natural resources. In fact, humans also interact with nature in order to create development for the purpose of sustainability. Other approaches emphasize the importance of certain aspects, such as emphasis on women through ecofeminism, emphasis on upholding human civilization as in ethnocentrism, and emphasis on non-human environmental sustainability without any attention to human interest as in naturalism, biocentrism, animalism and deep ecology. The group ecofeminism seems quite vague nowadays perhaps due to its inclination for the female gender only and less discussion on important roles of all parties. In fact, the struggle of women in environmental management in the context of research these days has been included by means of comprehensive social studies. For example, putting gender as a basis of acquiring information, as stated by Fisher and Greenberg (1996). Thus, the philosophy of ecofeminism is increasingly forgotten, even after a relatively long history of struggle has placed women as having an important role in the care of the environment. Overall, currently, the focus of the philosophy of knowledge on environmental management by most researchers is simply applying ecocentrism rather than other philosophies because of its inclusiveness of all gender groups, making it more comprehensive and appropriate.

\section{Conclusion}

Ecofeminism and philosophy of knowledge in environmental care is certainly one of the efforts made by women for decades. The aim is to change people's mindset to see that women should fight for the preservation of the environment alongside men. Although in the context of environmental management today indicates that ecofeminism is overlooked compared with ecocentrism, in terms of contribution of knowledge, it has become part of the legacy of philosophy or approach to managing the environment that could be seen as an alternative. The exploration of knowledge based on this philosophy clearly shows that it goes through its own process, in terms of ontology, epistemology, methodology, or axiology. Considering that all aspects of the philosophy of knowledge exist, then the struggle of proponents of ecofeminism is obvious and systematic in terms of its academic structure.

\section{References}

Abbot, P., Wallace, C., \& Tyler, M. (1996). An introduction to sociology: feminist perspectives. 2nd Edition. London: Routledge. Anderson, E. (2011). Feminist epistemology and philosophy of science. Stanford: Stanford University Press. Biehl, J. (1991). Rethinking eco-feminist politics. Boston: South End Press.

Blain, V., Clements, P. \& Grundy, I. (1990). The feminist companion to literature in English: women writers from the Middle Ages to the 
present. New Haven: Yale University Press.

Creswell, J. (1998). Qualitative inquiry and research design: choosing among five traditions. Thousand Oaks, California: Sage Publications.

Creswell, J. (2003). Research design: qualitative, quantitative, and mixed methods approaches. Thousand Oaks: Sage Publications.

Farber, M. (2006). The foundation of phenomenology. Cambridge: Harvard University Press.

Farley, M. (2003). Prostitution and the invisibility of harm. Women and Therapy, 26(3-4), 247-280.

Findlay, J.N. (1970). Axiological ethics. New York: Macmillan.

Firestone, S. (1970). The dialectic of sex: the case for feminist revolution. New York: William Morrow.

Fisher, S. \& Greenberg, R.P. (1996). Freud scientifically reappraised: testing the theories and therapy. New York: John Wiley.

Franklin, M.I. (2012). Understanding research: coping with the quantitative-qualitative divide. London and New York: Routledge.

Freedman, E.B. (2003). No turning back: the history of feminism and the future of women. New York: Ballantine Books.

Fricker, M. (2009). Epistemic injustice: power and the ethics of knowing. Oxford: Oxford University Press

Gaard, G. (1998). Ecological politics: ecofeminists and the greens. Philadelphia: Temple University Press.

Gaard, G. (2001). Ecofeminism and ecocomposition. Albany: State University of New York Press.

Gracia, G.M-P. (1989). Ecologia: women, environment and politic in Venezuela. Cited in Radcliffe, S.A. \& Westwood, S. (Editors) Viva: women and popular protest in Latin America. New York: Routledge.

Griffin, S. (1978). Women and nurture: the roaring inside her. New York: Harper \& Row.

Griswold, C.L. (2001). Platonic writings or platonic readings. Pennsylvania: Penn. State Press.

Guba, E. \& Lincoln, Y. (1989). Fourth generation evaluation. Newbury Park, California: Sage Publications.

Hampson, D. (1990). Theology and feminism. Oxford: Basil Blackwell.

Harding, S. (2003). The feminist standpoint theory reader: intellectual and political controversies. London: Routledge.

Jacquette, D. (2002). Ontology. Montreal: Mc-Gill-Queens's University Press.

Jahi, J.M. (1996). Impak pembangunan terhadap alam sekitar. Bangi: Penerbit Universiti Kebangsaan Malaysia.

Lindlof, T.R. \& Taylor, B.C. (2002). Qualitative communication research methods. Thousand Oaks, Calif: Sage Publications.

Lynn, H.N. (1990). Who knows: from Quine to a feminist empiricism. Philadelphia: Temple University Press.

MacGregor, S. (2006). Beyond mothering earth: ecological citizenship and the politics of care. Vancouver: UBC Press.

McFague, S. (1987). Models of God: theology for an ecological, nuclear age. Philadelphia: Fortress Press.

Messer-Davidow, E. (2002). Disciplining feminism: from social activism to academic discourse. Durham: Duke University Press.

Mohammad Hatta. (1982). Alam fikiran Yunani. Kuala Lumpur: Dewan Bahasa dan Pustaka.

Narayan, U. (1997). Dislocating cultures: identities, traditions, and Third-World Feminism. New York: Routledge.

Ogunyemi, C.O. (1985). Womanism: the dynamics of the contemporary black female novel in English. Journal of Women in Culture and Society, 11(1), 63-80.

Price, J. \& Shildrick, M. (1999). Feminist Theory and the body: a reader. New York: Routledge.

Rescher, N. (2005). Value matters: studies in axiology. Frankfurt: Ontos Verla.

Ritchie, J. \& Lewis, J. (2003). Qualitative research practice: a guide for social science students and researchers. London: Sage Publications.

Ruether, R.R. (2003). Ecofeminism and globalization. Lanham: Rowman and Littlefield.

Shiva, V. (1988). Staying alive: women, ecology and development. London: Zed Books.

Strong, H. (1995). Ecological and spiritual revolution. Our Planet, 7(3), 25-49.

Vardey, L. (1995). God in all worlds: an anthology of contemporary spiritual writing. New York: Random House. 